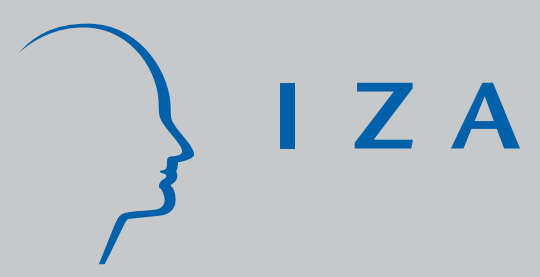

IZA DP No. 447

\title{
Mobility within Europe - What do we (still not)
} know?

Michael Fertig

Christoph M. Schmidt

March 2002 


\title{
Mobility within Europe - What do we (still not) know?
}

\author{
Michael Fertig \\ University of Heidelberg and IZA, Bonn \\ Christoph M. Schmidt \\ University of Heidelberg, CEPR, London and IZA, Bonn
}

Discussion Paper No. 447
March 2002

IZA

P.O. Box 7240

D-53072 Bonn

Germany

Tel.: +49-228-3894-0

Fax: +49-228-3894-210

Email: iza@iza.org

This Discussion Paper is issued within the framework of IZA's research area Evaluation of Labor Market Policies and Projects. Any opinions expressed here are those of the author(s) and not those of the institute. Research disseminated by IZA may include views on policy, but the institute itself takes no institutional policy positions.

The Institute for the Study of Labor (IZA) in Bonn is a local and virtual international research center and a place of communication between science, politics and business. IZA is an independent, nonprofit limited liability company (Gesellschaft mit beschränkter Haftung) supported by the Deutsche Post AG. The center is associated with the University of Bonn and offers a stimulating research environment through its research networks, research support, and visitors and doctoral programs. IZA engages in (i) original and internationally competitive research in all fields of labor economics, (ii) development of policy concepts, and (iii) dissemination of research results and concepts to the interested public. The current research program deals with (1) mobility and flexibility of labor, (2) internationalization of labor markets, (3) the welfare state and labor markets, (4) labor markets in transition countries, (5) the future of labor, (6) evaluation of labor market policies and projects and (7) general labor economics.

IZA Discussion Papers often represent preliminary work and are circulated to encourage discussion. Citation of such a paper should account for its provisional character. A revised version may be available on the IZA website (www.iza.org) or directly from the author. 
IZA Discussion Paper No. 447

March 2002

\section{ABSTRACT}

\section{Mobility within Europe - What do we (still not) know?*}

Intensified European integration, enlargement of the EU, and increasing migration activity worldwide have pushed migration and migration policy to the forefront of the European agenda. This paper identifies the salient questions to be addressed by any educated migration policy. It embeds this discussion into a systematic classification of economic migration research according to its major conceptual and applied questions. The state of theoretical and empirical research in the different strands of the taxonomy is reviewed briefly, with a focus on European aspects. Furthermore, we offer some empirical evidence on the determinants of intra-EU-migration by an analysis of the Eurobarometer. The paper concludes with an outline of the major open research questions in the European context. Specifically, at this juncture the generation of individual-based detailed and comprehensive data material covering the phenomenon is imperative.

JEL Classification: F22, J61

Keywords: Labor mobility, migration intention, intra-EU migration

Christoph M. Schmidt

Department of Economics

University of Heidelberg

Grabengasse 14

69117 Heidelberg

Fax: +49 6221543640

Email: schmidt@uni-hd.de

\footnotetext{
* This paper is based on evidence presented to the House of Lords Select Committee F (Social Affairs, Education and Home Affairs). Responsibility for the views expressed in this paper is solely that of the authors.
} 


\section{Introduction}

More than fifty years after World War II, societies in Europe have transformed their composition to an extent that the founding fathers of a unified Europe could not have anticipated. In particular, many societies in Europe have been shaped by their intense and multi-faceted immigration experience, leading to the variegated societies we observe today. Certainly, much of this change is a reflection of international developments, most notably European economic and political integration itself, but also the demise of socialism in Eastern Europe, the consequences of post-war baby booms and baby busts, and the ensuing population ageing. Yet, neither is the phenomenon of migration well understood, nor is it obvious how to predict its development into the future.

The current situation on many European labor markets is characterized by rather high average unemployment. However, there is simultaneously a shortage of high-qualified labor in many countries. In Germany, for instance, the information technology sector is persistently unable to fill its vacancies out of the pool of German unemployed. Indeed, many observers argue for an immigration policy directed at actively recruiting highly qualified workers from abroad (see e.g. ZimMERMANN ET AL. (2002)). This position reflects a growing perception that the industrialized countries are involved in a constant competition for high-skilled workers (for an overview on high-skilled migration see e.g. REGETs (2001)). At least within Europe the legal arrangements facilitate this competition: the free movement-agreement of the European Union, in principle, smoothes the way for labor migration across national borders. Yet, mobility within the European Union still seems rather low or even negligible. The reasons for this phenomenon are unclear, however, since the determinants and consequences of intra-EU-migration are widely unresearched.

The aim of this paper is, therefore, to identify the salient policy-relevant questions regarding the causes and consequences of external immigration and of migration within the European Union and its changing borders. Naturally, the European experience with continuous and substantial migration from outside the European Union as well as possibly considerable future flows across national borders within it, pose a set of questions which are important for the future economic and demographic developments in Europe. The provision of convincing answers to these questions could serve as one cornerstone for a rational economic policy on the level of the EU as well as for the individual member states. Some of the most important questions are:

1. Do we need or at least benefit from immigration from outside the EU?

2. Do we need (more) migration within the EU?

3. Which factors determine immigration movements from outside the EU and which are the driving factors or main impediments for mobility within the EU? 
4. What will happen to these processes after the enlargement of the EU towards the countries of Central and Eastern Europe?

5. What are the consequences to be expected from future migration movements within and from outside the EU?

6. What are the fundamental ingredients of an educated and rational immigration policy able to cope with future societal challenges?

As a point of departure we briefly survey some stylized facts on the European migration experience in section 2 . Furthermore, we review the theoretical and empirical challenges involved in providing answers to these questions and provide a brief summary of the contributions of economic migration research in this endeavor. To this end we outline in section 3 the state of discussion in the received literature on economic migration research and derive a set of interrelated research sub-fields. In our assessment these are the fields which have to be pursued necessarily in the future if we want to enhance our understanding of the questions raised by migration movements. Moreover, we provide some empirical evidence on the intentions of young Europeans to work or study abroad in section 4. Finally, section 5 offers some conclusions.

\section{Migration Within the EU - The Current Situation}

Is mobility within Europe too low? The answer to this question clearly depends on what is perceived as the optimal migration activity. This in turn involves a rather accurate assessment of the - perhaps diverging - magnitudes of migration needed to solve specific economic problems. It seems fair to argue that in the long run one of these problems carries particular weoght: in the next decades demographic considerations will be decisive for the European societies. Migration could help to alleviate the ageing of the population (see Bonin (2001) and SchmidT (2000) for the case of Germany). However, this alleviation is unlikely to come from within the EU. Table 1 reveals that the demographic structure of many EU countries is comparable in that they all suffer from low birth rates and continuously increasing life expectancy. Therefore, in the long-run it is rather unlikely that intra-EU migration alone could suffice to contain the demographic burden. 
Table 1: Population Movements 1999 per 1,000 Inhabitants

\begin{tabular}{|c|c|c|c|c|c|}
\hline "COUNTRY & $\overline{\text { BIRTHS }}$ & PEATHS & $\begin{array}{c}\text { NATURAL } \\
\text { POPULATION } \\
\text { GROWTH }\end{array}$ & $\begin{array}{c}\text { NET } \\
\text { MIGRATION* }\end{array}$ & $\begin{array}{c}\text { PoPULATION } \\
\text { GROWTH }\end{array}$ \\
\hline EU-15 & 10.7 & 9.9 & 0.7 & 1.9 & 2.6 \\
\hline Austria & 9.7 & 9.7 & 0.0 & 1.1 & 1.1 \\
\hline Belgium & 11.2 & 10.3 & 0.9 & 1.6 & 2.5 \\
\hline Denmark & 12.4 & 11.1 & 1.3 & 1.8 & 3.1 \\
\hline Finland & 11.1 & 9.6 & 1.6 & 0.7 & 2.3 \\
\hline France & 12.6 & 9.2 & 3.4 & 0.8 & 4.3 \\
\hline Germany & 9.3 & 10.3 & -0.9 & 2.5 & 1.6 \\
\hline Greece & 9.7 & 9.8 & -0.1 & 2.4 & 2.3 \\
\hline Ireland & 14.2 & 8.4 & 5.8 & 4.9 & 10.7 \\
\hline Italy & 9.3 & 9.9 & -0.6 & 1.8 & 1.2 \\
\hline Luxembourg & 12.9 & 8.8 & 4.1 & 10.9 & 15.0 \\
\hline Netherlands & 12.7 & 8.9 & 3.8 & 2.8 & 6.6 \\
\hline Portugal & 11.5 & 10.8 & 0.7 & 1.1 & 1.8 \\
\hline Spain & 9.5 & 9.3 & 0.2 & 1.0 & 1.2 \\
\hline Sweden & 10.0 & 10.7 & -0.7 & 1.5 & 0.8 \\
\hline United Kingdom & 11.8 & 10.6 & 1.2 & 2.7 & 3.9 \\
\hline
\end{tabular}

In the short- and medium-run perspective labor market considerations can clearly claim serious attention. If labor markets are competitive and work without frictions there should be no regional, no inter-sectoral nor occupational wage differences. Such differences, however, exist (see Table 2) and turn out to be highly persistent (see e.g. DeNEw AND SCHMIDT (1994) and HAisken-DeNew AND SCHMidT (1997)). Therefore, migration within Europe could serve as an adjustment mechanism. The rather low rates of intra-EU migration despite existing wage and unemployment differentials between EU countries are striking. They might reflect rather high cost of moving away from the home country. These cost somprise physic components, but also the possibly dramatic loss of country-specific human capital. Arguably, existing economic differences between countries should exhibit the greatest incentives to migrate for younger people (say, 20 to 40 years of age) since these cohorts should have the highest return to invest in the migration decision and the lowest cost of emigrating. Table 2 reveals that there is indeed substantial variation in the unemployment rate for this core age group across EU countries whereas the population share of this age group is rather constant. 
Table 2: EU-15 Population and Core Age Group (age 20-40) in 1998

\begin{tabular}{|c|c|c|c|c|}
\hline COUNTRY & $\begin{array}{c}\text { POPULATION } \\
\text { IN } 1,000\end{array}$ & $\begin{array}{c}\text { Core AGE } \\
\text { Group } \\
\text { IN } \%\end{array}$ & $\begin{array}{c}\text { UnEMPlOYMENT RATE } \\
\text { OF CoRE AGE } \\
\text { GRoup IN \% }\end{array}$ & $\begin{array}{c}\text { AVERAGE } \\
\text { EARNINGS } \\
\text { PER HOUR }^{*}\end{array}$ \\
\hline EU-15 & $375 \quad 457.8$ & 29.75 & 8.29 & 11.48 \\
\hline Austria & 8082.8 & 28.66 & 5.34 & 13.05 \\
\hline Belgium & 10213.8 & 29.16 & 12.11 & 10.47 \\
\hline Denmark & 5313.6 & 29.48 & 6.17 & 23.24 \\
\hline Finland & 5159.6 & 29.88 & 9.55 & 12.32 \\
\hline France & 58973.2 & 32.37 & 16.03 & 10.51 \\
\hline Germany & 82037.0 & 28.51 & 6.95 & 12.94 \\
\hline Greece & 10521.7 & 30.25 & 10.38 & 4.63 \\
\hline Ireland & 3734.9 & 30.54 & 10.46 & 9.45 \\
\hline Italy & 57612.6 & 30.34 & 11.20 & n.a. \\
\hline Luxembourg & 429.2 & 30.52 & 1.90 & 11.14 \\
\hline Netherlands & 15760.2 & 31.00 & 3.41 & 14.91 \\
\hline Portugal & 9979.5 & 31.08 & 4.74 & 3.83 \\
\hline Spain & 39394.3 & 26.80 & 15.67 & 9.15 \\
\hline Sweden & 8854.3 & 26.85 & 6.06 & 12.00 \\
\hline United Kingdom & 59391.1 & 29.14 & 4.36 & 13.08 \\
\hline
\end{tabular}

Although the intensity of the current debate and the uninformed argumentation of many of its participants might suggest that Europe is a stranger to the phenomenon, this region possesses a rather intense migration experience, historically as well as recent. Overall, since the end of World War II Europe as a whole underwent a transition process to an immigration region. It had clearly been an emigration region in the 19th century (see e.g. Chiswick And HatTon (2001)). As a consequence of this continuous influx, many European societies today contain large immigrant populations. Moreover, second-generation migrants are a sizeable fraction of the younger European population, shaping European society in an important way. Table 3 reports some evidence for this development.

Table 3 demonstrates that many countries of the EU display a considerable share of non-citizens in their population as well as in their labor force. However, there is also a substantial variation among these countries. Neglecting the exceptional situation of Luxembourg, the average share of non-citizens in the population of the existing EU countries is $4.65 \%$ and the average share in the labor force amounts to $4.25 \%$. Yet, Austria, Belgium, France, Germany, and Sweden display substantially higher non-citizen shares, whereas the fraction of non-citizens in the population and labor force of the Mediteranean countries, but also of the United Kingdom and Finland are clearly lying below average. 
Table 3: Foreign or Foreign-Born Population and Labor Force in Selected European Countries in 1996

\begin{tabular}{l|rc|rc}
\hline \hline Country & \multicolumn{2}{|c}{ ForEIGN Population } & \multicolumn{2}{c}{ ForEIGN LABOR ForCE } \\
& Thousands & $\begin{array}{r}\text { \% of Total } \\
\text { \% of Total }\end{array}$ & Thousands & Labor Force \\
\hline Austria & 728 & 9.0 & 328 & 10.0 \\
Belgium & 912 & 9.0 & 341 & 8.1 \\
Denmark & 238 & 4.7 & 84 & 3.0 \\
Finland & 74 & 1.4 & 19 & 0.8 \\
France & 3,597 & 6.3 & 1,605 & 6.3 \\
Germany & 7,314 & 8.9 & 2,559 & 9.1 \\
Ireland & 118 & 3.2 & 52 & 3.5 \\
Italy & 1,096 & 2.0 & 332 & 1.7 \\
Luxembourg & 143 & 34.1 & 118 & 53.8 \\
Netherlands & 680 & 4.4 & 218 & 3.1 \\
Portugal & 173 & 1.7 & 87 & 1.8 \\
Spain & 539 & 1.3 & 162 & 1.0 \\
Sweden & 527 & 6.0 & 218 & 5.1 \\
United Kingdom & 1,972 & 3.4 & 878 & 3.4 \\
\hline \hline
\end{tabular}

Source: OECD (1998). Figures for France are for 1990. Figures for Greece not available.

In absolute terms Germany displays the largest non-citizen community among these countries. Table 4 reports the most current figures for the country-of-citizenship composition of non-citizens living in Germany. The table reveals that the majority of foreigners currently living in Germany are citizens of a European country, with citizens of Turkey being the largest group.

Table 4: The Composition of Non-Citizens in Germany in 2000

\begin{tabular}{l|rc}
\hline \hline CITIZEN OF & THOUSANDS & PER CENT \\
\hline European Countries: & & \\
Turkey & $1,998.5$ & 27.4 \\
EU-Countries & $1,872.7$ & 25.7 \\
Yugoslavia & 662.5 & 9.1 \\
Poland & 301.4 & 4.1 \\
Croatia & 216.8 & 3.0 \\
Bosnia & 156.3 & 2.1 \\
Romania & 90.1 & 1.2 \\
Hungary & 54.4 & 0.7 \\
Bulgaria & 34.4 & 0.5 \\
Switzerland & 38.0 & 0.5 \\
Non-European Countries: & & \\
African Countries & 299.3 & 4.1 \\
American Countries & 213.3 & 2.9 \\
Asian Countries & 213.3 & 11.5 \\
Australia and Oceania & 10.4 & 0.1 \\
Stateless and Unknown & 74.3 & 1.0 \\
\hline \multicolumn{2}{l}{ Source: STATISTISCHES BundesAmT (2001). All figures for 31.12.2000. } \\
\hline \multicolumn{2}{l}{}
\end{tabular}


Citizens of Turkey and of EU-countries comprise more than $53 \%$ of the stock of foreigners currently residing in Germany. Together with the states of former Yugoslavia these countries represent more than $67 \%$ of the foreign population share. This population stock is the result of a steady immigration of people to Germany since the end of World War II. However, the composition of these immigration flows as well as their magnitude varied substantially over time (for more details on the historical developments for the case of Germany see e.g. Schmidt (1996) and Schmidt AND Zimmermann (1992)).

Table 5: Population Share of EU- and Non-EU-Foreigners in Percent, 1985-1998

\begin{tabular}{l|cccc|cccc}
\hline \hline & \multicolumn{4}{|c}{ EU-FOREIGNERS } & \multicolumn{3}{c}{ NON-EU-FOREIGNERS } \\
Country & 1985 & 1990 & 1995 & 1998 & 1985 & 1990 & 1995 & 1998 \\
\hline EU-15 & 1.5 & 1.5 & 1.6 & 1.6 & 2.3 & 2.6 & 3.3 & 3.5 \\
Austria & n.a. & 1.0 & n.a. & 1.2 & n.a. & 5.6 & n.a. & 7.9 \\
Belgium & 6.0 & 5.5 & 5.5 & 5.5 & 3.2 & 3.4 & 3.7 & 3.3 \\
Denmark & 0.7 & 0.7 & 0.9 & 1.0 & 1.4 & 2.2 & 2.9 & 3.7 \\
Finland & 0.2 & 0.1 & 0.3 & 0.3 & 0.1 & 0.3 & 1.0 & 1.3 \\
France & n.a. & 2.3 & n.a. & n.a. & n.a. & 4.0 & n.a. & n.a. \\
Germany & 2.0 & 1.9 & 2.2 & 2.3 & 3.6 & 4.2 & 6.4 & 6.7 \\
Greece & 0.4 & 0.5 & 0.4 & 0.4 & 2.0 & 1.7 & 1.0 & 1.2 \\
Ireland & 1.8 & 1.8 & 2.0 & 2.3 & 0.4 & 0.5 & 0.6 & 0.7 \\
Italy & n.a. & n.a. & 0.2 & 0.2 & n.a. & n.a. & 1.0 & 1.3 \\
Luxembourg & n.a. & 25.4 & 29.5 & 31.0 & n.a. & 3.4 & 3.1 & 3.8 \\
Netherlands & 1.3 & 1.1 & 1.3 & 1.2 & 2.6 & 3.2 & 3.7 & 3.1 \\
Portugal & 0.2 & 0.3 & 0.4 & 0.5 & 0.6 & 0.7 & 1.2 & 1.3 \\
Spain & 0.4 & 0.6 & 0.6 & 0.7 & 0.2 & 0.4 & 0.6 & 0.9 \\
Sweden & 2.6 & 2.3 & 2.0 & 2.0 & 2.1 & 3.0 & 4.1 & 3.9 \\
United Kingdom & 1.5 & 1.6 & 1.6 & 1.4 & 2.5 & 2.7 & 2.1 & 2.3 \\
\hline \hline
\end{tabular}

* Source: Eurostat (2000).

Table 5 reveals that workers from EU countries have accounted for a relatively steady share of the population in the Eu-15 countries over time, whereas the share of foreigners from Non-EU countries has been increasing considerably within the time period from 1985 to 1998 . These figures, however, do in all likelihood not reveal the true mobility within Europe since what is recorded as an immigrant or foreigner by these statistics are individuals who change their place of residence for a longer time period. In other words, these figures do not report short-term moves of individuals working abroad for only a couple of months. Furthermore, they do not reveal any information about cross-border commuters or seasonal workers. It is, therefore, very likely that the figures in Table $\mathbf{5}$ paint only part of the overall picture on mobility within the European Union. It is presumably rather a lower bound on the phenomenon.

More generally, common perceptions and traditional recording of migration may be an inappropriate description of current population movements. By contrast, to provide a more encompassing view, it is necessary to consider current and future forms of any kind of cross-border movements, their 
relationship to individual behavior, their relationship to more integrated economies and to new forms of technology and communication. Not the least reason for this widened attention is that the process of integration of immigrants is in all likelihood closely related to the (expected) duration of migration (see e.g. Dustmann (1996)). Understanding the reasons for different forms of mobility is one of the key elements for analyzing the economic performance of temporary and permanent migrants as well as their economic impact on both the origin and the destination country's societies.

The following section aims at providing a common frame of reference for answering these questions in the context of economic migration research together with a brief review of the contributions of this research. This discussion together with the preliminary evidence on the migration intentions of young Europeans presented in section 4 will serve as the basis for an identification of necessary future work.

\section{What Do We Know?}

For an overview on the state of discussion on the questions raised above it is helpful to proceed along the lines of a common conceptual framework. Naturally, there is no unique, all-encompassing theoretical framework linking together all aspects of the different topics of economic migration research. However, it is possible to outline a conceptual framework which provides the brackets for the discussion of the interrelated and complex issues of economic migration research. This framework demonstrates that the questions raised above are by no means independent and that they are closely related to many other aspects of economic policy.

\subsection{The Conceptual Framework}

Economic research concerning migration issues can be conceptualized into three broad fields, each of them interrelated with each other. All these research areas carry important implications for immigration policy, again reflecting an intimate relationship between them. These fields may be described most sensibly by the following set of research questions:

1. Which factors determine the decision to migrate, i.e. which are the motives or driving forces behind observed immigration flows? Naturally, since the decision to migrate is in all likelihood the outcome of a systematic process, the characteristics of those who decide to relocate from their original home to a new destination are hardly a random sample of the indigenous population of either country. Understanding the composition of migration flows seems therefore to be an important 
prerequisite for the analysis both of migrant performance and the impact of immigration, which are the remaining two aspects of economic migration research.

2. Which factors determine the economic performance of immigrants in the destination country, i.e. do migrants' wages, employment prospects or the risk to depend on welfare payments converge or diverge to those of comparable natives as the duration of residence unfolds and what are the reasons for these developments? What structural explanation can be offered for the observed convergence or divergence patterns, i.e. is it assimilation or discrimination? Related aspects are the determinants of the perception of as well as the attitudes towards immigrants by the native population in the destination country.

3. Which factors determine the economic impact of immigration on the destination country as a whole or on the population indigenous to the destination country, i.e. does immigration, for instance, exhibit a significant impact on the age structure of the destination country's society or does it reduce the wages or employment prospects of, say, low-skilled natives or resident migrants of preceding entry cohorts, and if so, what are the mechanisms at work?

These three areas are interrelated with each other and exhibit a close connection to immigration policy. Clearly, the composition of immigration flows can, at least in principle, be regulated by different policy regimes yielding a different skill or country-of-origin mix of observable inflows. Since formal and informal human capital endowments determine the economic performance of immigrants in the destination country and the transferability of these endowments may vary with the country of origin, immigration policy plays a decisive role for the economic performance of immigrants. Moreover, economic prospects of immigrants, the impact of immigration on the destination countries' economies and the perception of migrants by the natives are certainly closely related and might exhibit repercussions on the decision of potential migrants to enter the country.

\subsection{The State of Discussion}

\section{The Migration Decision}

The traditional approach to explaining aggregate migration flows departs at differential developments of economic activity (per capita), unemployment rates and other socio-demographic factors, such as geographic distance, a common history or common language (see e.g. HARRIS AND TODARO (1970) for a seminal paper; FERTig (2001) and Vogler And RotTe (2001) are applications for the case of Germany). Pinning down any stable relationship between the economic factors and immigration activities has been notoriously difficult throughout this literature. This has made the creation of a satisfactory connection between the in parts overwhelmingly sophisticated 
economic theory of the migration decision and the - at best - scarce evidence for the validity of its predictions a very frustrating endeavor.

FERTIG AND SCHMIDT (2000) take a completely different approach at modelling aggregate immigration activity, with the principal aim of forecasting net immigration into the future. In this study, the crucial role of demographics for migration activity is placed in the focus of the discussion. It has been demonstrated in numerous empirical analyses of migration activity historical as well as recent - that migrants tend to move from origin to destination at young prime age. Thus, the relative prevalence of this age group in the population at the origin is necessarily a major determinant of the actual migration potential and, in consequence, activity from this source. On the basis of these considerations, FERTIG AND SCHMIDT (2000) conclude that even if EU enlargement were to lift all legal obstacles for East-West migration, the ensuing migration flows would likely be only of moderate magnitude.

\section{The Economic Performance of Migrants}

For the purpose of providing convincing answers to the questions on the need for migration and its economic impact, it is of central concern to have a clear understanding of the assimilation process of migrants in the destination country. The focus of economic migration research has been on a single aspect of this process, relative wage dynamics of migrant workers throughout their labor market career. Before we proceed to discuss the impact of immigration we, therefore, briefly review the issues involved in the analysis of the economic performance of immigrants.

It has been demonstrated in numerous studies (see among others DusTMANN (1993) and SCHMIDT (1997) for Germany) that skills play a dominant role for immigrant performance, whether acquired in formal curriculae as secondary or post-secondary schooling and vocational training, or informally as experience in the labor market, or as manifestation of intrinsic personal traits such as cognitive ability or motivation. In general, migrants acquire productive capacity in their origin country, but only part of this human capital can be transferred to the labor market at the destination. Consequently, the young adults arriving at their new home possess a lower earnings capacity, and - since their labor supply is typically inelastic - relatively low wage earnings. Over their time of residence, they tend to acquire the lacking human capital, such as the language spoken at the destination - their low initial earnings capacity implies that the opportunity cost of their investment are relatively low, making substantial human capital acquisition likely.

All the analyses on the relative labor market performance of migrants rest their interpretation on a crucial, and typically completely undiscussed, identification assumption. Wage differences can only be used as a perfect measure of disparities in economic productivity, if the labor market functions without any trace of discrimination and any legal barriers to wage parity, of course. On the other hand, interpreting any unexplained wage differential as a re- 
flection of discrimination would require an equally strong and hardly more plausible implicit identification assumption - the absence of migrant-native differences in productive capacity once formal characteristics are controlled for. Yet, the two identification assumptions discussed here allow the interpretation of reduced-form wage dynamics in terms of structural ideas, assimilation or discrimination, although all the evidence merely pertains to unexplained migrant-native wage differentials. Therefore, the decisive problem in this endeavor is: what is the valid identification assumption? It is important to note that these assumptions must remain untestable, and their validity has to be judged on the basis of economic reasoning.

Similar considerations pertain to that aspect of research on immigrant assimilation which has received most attention in the North-American debate the role of cohort effects. It has been argued adamantly by BoRJAS (1987), (1991) and discussed intensely by subsequent anlysts (see e.g. LALONDE AND TOPEL (1991) and YuEngert (1994)) that the inherent productive capacity of immigrant cohorts to the United States varies drastically over time. Specifically, the extent of this variation and its link to changes in the legal setting are at issue. Again, a fundamental identification problem arises, since the impact of economic assimilation, the affiliation with varying cohorts, and the effect of a changing wage distribution cannot be identified separately without further identification assumptions.

\section{The Economic Impact of Immigration}

While relative individual economic performance is a matter of direct comparison of an appropriate outcome measure, i.e. wages or employment success, between the individuals of interest - migrants - and a comparison group natives, the economic impact of immigration unfolds in an indirect fashion via market reactions, and is therefore much more complex as an object of investigation. Conceptually, additional immigration shifts the relevant labor supply curve outward - with the first problem for any empirical strategy arising as the question what exactly is "relevant", the local labor market, the skill group etc.? The consequences, in terms of employment and wages for this relevant group, as well as for all other groups of labor - with unskilled native workers being the most prominent case in the public debate - are first of all a matter of the relative own elasticities of demand and supply and of the set of elasticities of complementarity with all other production factors.

Yet, the additional labor supply is only part of the story, since product demand, and thus labor demand (on all other sub-markets) tend to be affected positively. On balance, it might not be the case at all that immigration harms any group of native workers via the crowding out that the constantoutput reasoning typically applied seems to suggest. In fact, the matter is entirely empirical. Nevertheless, even at the theoretical level many facets relevant for the real world might complicate the analysis, for instance the necessity to account for an increasing variety of products via immigration, or the consequences of institutionalized wage rigidities (see SCHMIDT ET AL. 
(1994)).

The empirical challenge is to isolate immigration induced shifts in labor supply which can be treated as if they were set in an ideal experiment, in other words as exogenous. Several strategies can be found in the literature regarding the definition of the appropriate sub-market. All these analyses face the common problem of non-experimental research: the extent of additional immigration does not vary randomly across time and space, as in a laboratory experiment, but is rather the outcome of systematic forces. Specifically, more attractive destinations will typically generate a larger influx of immigrants. Comparing the relevant economic outcome measures, native employment rates say, across regions will typically confuse the impact of immigration with the underlying reason making the area particularly attractive.

For the case of Europe, empirical evidence on the economic impact of immigration (see among others BAUER (1998), HAISKEN-DeNEw (1996), Hunt (1992) and Pischke And Velling (1997)) suggests that the derivation of robust qualitative results is a difficult, if not hopeless task, given the nature of the data material, and the inherent heterogeneity of the phenomenon. As a tentative summary, it seems apparent that any displacement effects of additional migration are small in magnitude, with zero being a plausible point estimate. So far it has not been possible to quantify any of the presumably positive demand side effects working via goods markets, let alone indirect (positive) effects of increasing variety of products and services, or (negative) effects of excessive crowding on the housing market.

One of the most contentious issues in this context regards the welfare state. The concern over this problem in principle reflects legitimate reservations about the fiscal and political viability of a welfare state potentially acting as a magnet to migrants, yet being underwritten by a native electorate. Most of the research on this topic has been conducted in the US and Canada. However, neither the empirical results regarding the trends in immigrant welfare nor the institutional arrangements shaping the environment for immigrants' welfare use are easily translated from North America to the European context. Most of all, the historical developments governing size and composition of immigrant influx to Europe were quite distinct.

An interesting piece of evidence for the case of the US is provided by the study of Levine And Zimmermann (1999). They utilize the quasilaboratory nature provided by the idiosyncratically acting US states to approximate as close as possible an appropriately designed experiment. In sum, they find little evidence for the welfare magnet hypothesis. Unfortunately, despite its importance for the assessment of the impact of immigration, the empirical literature for Europe is rather scarce, with BLundell ET AL. (1988) for the UK and Fertig and Schmidt (2001) for the Germany being two of a few exceptions. 
In particular, the latter study suggests that, while the population of noncitizens in Germany indeed displays a relatively large welfare dependence, this relative pattern is turned on its head when one compares genuinely comparable individuals. That is, the apparently high welfare dependence of migrants is a reflection of the guest-worker recruitment policy of the late 1960's and early 1970's - mainly seeking to attract unskilled workers and their families. It is not a reflection of low intrinsic qualities, but rather of the continuing importance of formal skills on the German labor market. Yet, the paper by FERTIG AND SCHMIDT (2001) also demonstrates that the subtlety of these comparisons is not at all well understood by individual survey respondents.

\section{The Migration Intentions of Young Euro- peans - Some Evidence}

For the case of mobility within Europe empirical evidence on the determinants of cross-border moves is rather scarce. In order to present some first, rather descriptive evidence we analyze the Eurobarometer, a public opinion survey of social and political attitudes conducted on behalf of the European Commission two or more times a year in all member states of the EU. Specifically, in our analysis we utilize the second wave of the 1997 Eurobarometer survey conducted among young European between 15 and 24 years of age at the time of the interview.

This wave of the survey aims at providing a portrait on the personal life situation of young Europeans, their organizational membership and activities as well as their attitudes towards social problems, foreign people, and employment issues. Furthermore, these young people who were brought up at a time in which the idea of a unified Europe had already been widely recognized and was established in institutional terms to a fair degree were asked for their perception of the European Union and the possibilities to work or study abroad.

We utilize the answer distribution of French, German and UK youth to analyze the correlates of the attitudes of these young people towards mobility in a wider sense. A description of the explanatory variables in our analysis is provided in Table A1 in the appendix. Table A2 provides some summary statistics. As a starting, point Table 6 displays the results from our analysis of the question "Which of the following, do you think 'being a citizen of the European Union' means?". Specifically, we analyze the correlates of the answer "The right to work in any country in the European Union" by individual respondents in a discrete choice framework. 
Table 6: Being a Citizen of the EU Means the Right to Work in any Country in the EU

\begin{tabular}{l|cc}
\hline \hline EXPLANATORY VARIABLE & MARGINAL EFFECT & T-VALUE \\
\hline German Nationality & 0.1213 & 5.23 \\
French Nationality & 0.1220 & 4.90 \\
Speaks Foreign Language & -0.0068 & -0.30 \\
Visited Foreign Country & 0.0312 & 1.51 \\
Being Female & -0.0332 & -1.77 \\
Still Studying & 0.0477 & 2.40 \\
Xenophobic Tendency & -0.0658 & -1.88 \\
Parents are Unemployed & -0.0495 & -1.05 \\
Parents have a High Degree of Education & 0.0501 & 2.14 \\
\hline Number of observations: 2,695. The reference category for the nationality \\
indicator is United Kingdom.
\end{tabular}

Estimation results suggest that ceteris paribus German and French youth exhibit a statistically significant higher probability to choose this answer category. The probability is approximately $12 \%$ higher than that of UK youth. Furthermore, young Europeans who are still studying or who have a highly educated parental background also tend to agree with this answer independently of the nationality. In these cases the probability to agree increases by around $5 \%$ each.

Table 7 extends the analysis further and reports the results of an analysis of the question "Let's suppose you want to work or study abroad, what, do you think, would be the main difficulty you would face?". There were several answer possibilities including "I would have language difficulties" or "I would be homesick" from which the young respondents had to choose exactly one. We analyze the correlates of the answers "I would have administrative difficulties" and "I would have difficulties to get my qualifications recognized" which we combined into one category.

Table 7: The Perception of the Difficulties of Working Abroad

\begin{tabular}{l|cc}
\hline \hline EXPLANATORY VARIABLE & MARGINAL EFFECT & T-VALUE \\
\hline German Nationality & -0.0014 & -0.13 \\
French Nationality & 0.0615 & 4.45 \\
Speaks Foreign Language & 0.0531 & 5.07 \\
Visited Foreign Country & 0.0209 & 2.26 \\
Being Female & -0.0033 & -0.40 \\
Still Studying & -0.0050 & -0.57 \\
Xenophobic Tendency & 0.0114 & 0.73 \\
Parents are Unemployed & -0.0487 & -2.17 \\
Parents have a High Degree of Education & 0.0002 & 0.02 \\
\hline Number of observations: 2,695. The reference category for the nationality \\
indicator is United Kingdom.
\end{tabular}

Table 7 reveals that ceteris paribus French respondents display a statistically significant higher probability of 6 percentage points to agree relatively 
to respondents from the UK whereas the perception of German youth does not differ from that of UK youth. Surprisingly, respondents which are able to speak a foreign language, as well as respondents who had gathered some experience with foreign countries by visiting them also exhibit a statistically higher probability to believe that there will be administrative difficulties involved in the decision to work abroad. Finally, respondents with unemployed parents display a significantly lower probability to agree since their main obstacle might rather lie in financial restrictions than in administrative difficulties.

Table 8 displays the results of our analysis of the (spontaneous) answer "I am not interested in working or studying abroad" on the question "Let's suppose you want to work or study abroad, what, do you think, would be the main difficulty you would face?"

Table 8: No Interest in Working or Studying Abroad

\begin{tabular}{l|cc}
\hline \hline EXPLANATORY VARIABLE & MARGINAL EFFECT & T-VALUE \\
\hline German Nationality & 0.1010 & 7.45 \\
French Nationality & 0.0070 & 0.46 \\
Speaks Foreign Language & -0.0190 & -1.72 \\
Visited Foreign Country & -0.0391 & -3.88 \\
Being Female & -0.0142 & -1.63 \\
Still Studying & -0.0118 & -1.28 \\
Xenophobic Tendency & 0.0441 & 2.66 \\
Parents are Unemployed & 0.0125 & 0.61 \\
Parents have a High Degree of Education & -0.0119 & -1.09 \\
\hline \hline
\end{tabular}

Number of observations: 2,695. The reference category for the nationality indicator is United Kingdom.

The results presented in Table 8 suggest that ceteris paribus German respondents are less willing to work or study abroad compared to young respondents from the United Kingdom and France. Young Europeans displaying xenophobic tendencies are also less willing to move abroad whereas individuals who already had been to a foreign country tend to disagree with this answer.

The evidence presented in the preceding tables is clearly of a descriptive nature and, therefore, cannot be interpreted in causal terms. Moreover, since the respondents were quite young at the time of the interview, the opinions expressed by them might change considerably over time. However, these results may well serve as a starting point for further research aiming at the analysis of the determinants of mobility of European individuals. Individual-level studies are certainly the conceptually most promising approach to receive a better understanding of these determinants than the usually conducted aggregate level studies. In studies at the aggregate level it is hardly possible to disentangle the complex aspects of the decision to work or study abroad. 


\section{Conclusions - What Remains to Be Done?}

The implications of the insights presented above are twofold. Firstly, the results suggest that for the case of Europe we are still in need of generating more empirical evidence on some of the most important questions of migration research. Researchers will hardly be able to complete this task without access to additional, individual-based data material. In light of this topic's importance for the future of the European society, it is hoped that any initiative to collect such data will be funded generously, and that policy makers and administrators alike will support such an endeavor.

It has to be the explicit aim of future research to aid in understanding the interplay between immigrant economic attainment and Europe's transition into a service-sector dominated and integrated economy. Among the specific aspects to be addressed by such a joint research are:

- Discrimination and ethnic concentration: Do immigrants to different European countries experience measurable discrimination in their wages and in employment opportunities given their human capital endowments, does this impact on their unemployment experience or welfare dependence and what is the role of ethnic concentration in these processes?

- Internal migration and the development of ethnic enclaves: Are the mobility patterns of individuals in Europe a reflection of the regional dispersion of job opportunities or of a tendency to develop and to benefit from the formal or informal networks of ethnic enclaves?

- Immigration policy, citizenship and participation in the political process: What are the various policies enacted across Europe to deal with the problem of integration of immigrants, which additional policies could be suggested, and which effects do the actual and the proposed policies have on the integration of those migrants?

Secondly, this research has to be conducted from a pronounced European perspective, i.e. as cross-country comparisons over time, relying on a common frame of reference. Such an ambitious task can hardly be performed by a handful of researchers alone. Instead, it is necessary to co-ordinate these endeavors on a European basis. In the light of the overwhelming relevance of these topics, it is hoped that representatives and institutions of the European Union will spend more effort in supporting the development of more and better knowledge on issues decisive for the future development of European societies. 


\section{References}

Bauer, Thomas K. (1998), Arbeitsmarkteffekte der Migration und Einwanderungspolitik: Eine Analyse für die Bundesrepublik Deutschland (Labor Market Effects of Migration and Migration Policy: An Analysis for Germany). Heidelberg: Physika.

Blundell, Richard, Vanessa Fry and Ian Walker (1988), Modelling the Take-Up of Means-Tested Benefits: The Case of Housing Benefits in the United Kingdom. Economic Journal, 98, 58-74.

Bonin, Holger (2001), Fiskalische Effekte der Zuwanderung nach Deutschland - Eine Generationenbilanz. IZA Discussion paper No. 305, IZA-Bonn.

Borjas, George J. (1987), Self-Selection and the Earnings of Immigrants. American Economic Review, 77, 531-553.

Borjas, George J. (1991), Immigration and Self-Selection. In: Abowd, John M. and Richard B. Freeman (EDs.), Immigration, Trade, and the Labor Market. Chicago and London: University of Chicago Press, 29-76.

Chiswick, Barry R. and Timothy Hatton (2001), International Migration and the Intergration of Labour Markets. Forthcoming in: Bordo, Michael D., Alan M. Taylor and Jeffrey G. Williamson, (eds.), Globalisation in Historical Perspective, NBER Conference Volume, Chicago: The University of Chicago Press.

Denew, John P. and Christoph M. Schmidt (1994), The Industrial Structure of German Earnings 1980-1990. Allgemeines Statistisches Archiv, 78, 141-159.

Dustmann, Christian (1993), Earnings Adjustments of Temporary Migrants. Journal of Population Economics, 6, 153-168.

Dustmann, Christian (1996), Return Migration: The European Experience. Economic Policy, 22, 213-242.

Fertig, Michael (2001), The Economic Impact of EU-Enlargement: Assessing the Migration Potential. Empirical Economics, 26, 707-720.

Fertig, Michael and Christoph M. Schmidt (2000), Aggregate Level Migration Studies as a Tool for Forecasting Future Migration Streams. In: Duajic, Slobodan (ED.), International Migration: Trends, Policy and Economic Impact. London: Routledge, 110-136.

Fertig, Michael and Christoph M. Schmidt (2001), First- and SecondGeneration Migrants in Germany - What Do We Know and What Do People 
Think? Forthcoming in: Rotte, Ralph (ED.), Migration Policy and the Economy: International Experiences.

Haisken-DeNew, John P. (1996), Migration and the Inter-Industry Wage Structure in Germany, Heidelberg/New York: Springer Verlag.

Haisken-DeNew, John P. and Christoph M. Schmidt (1997), InterIndustry and Inter-Region Differentials: Mechanics and Interpretation. The Review of Economics and Statistics, 79, 516-521.

Haisken-DeNew, John P. and Christoph M. Schmidt (1999), Industry Wage Differentials Revisited: A Longitudinal Comparison of Germany and USA (1984-1996), IZA Discussion Paper No. 98, IZA-Bonn.

Harris, J.R. and Michael P. Todaro (1970), Migration, Unemployment and Development: A Two-Sector Analysis. American Economic Review, 60, 126-142.

Hunt, Jennifer (1992), The Impact of the 1962 Repatriates from Algeria on the French Labor Market. Industrial and Labor Relations Review, 45, 556-572.

International Labor Organisation (ILO) (2002), LABORSTA Databank. http://laborsta.ilo.org

LaLonde, Robert J. and Robert H. Topel (1991), Labor Market Adjustments to Increased Immigration. In: ABOwD, John M. and RicharD B. Freeman (eds.), Immigration, Trade, and the Labor Market. Chicago and London: University of Chicago Press, 167-199.

Levine, Phillip B. And David J. Zimmerman (1999), An Empirical Analysis of the Welfare Magnet Debate Using the NLSY. Journal of Population Economics, 12, 391-409.

Pischke, Jörn-Steffen and Johannes Velling (1997), Employment Effects of Immigration to Germany: An Analysis Based on Local Labor Markets. Review of Economics \& Statistics. 79, 594-604.

Regets, Mark P. (2001), Research and Policy Issues in High-Skilled International Migration: A Perspective with Data from the United States.IZA Discussion No. 366, IZA-Bonn.

Schmidt, Christoph M. (1996), German Economic Growth After the Demise of Socialism: The Potential Contribution of East-West Migration. Jahrbuch für Wirtschaftsgeschichte, 2, 109-126.

Schmidt, Christoph M. (1997), Immigrant Performance in Germany: La- 
bor Earnings of Ethnic German Migrants and Foreign Guest-Workers. The Quarterly Review of Economics and Finance, 37, 379-397.

Schmidt, Christoph M. (2000), Reconstructing Germany: The Demographic Impact of Immigration During the Post-War Era. mimeo., University of Heidelberg.

Schmidt, Christoph M., Stiltz, Anette and Klaus F. ZimmerMANN (1994), Mass Migration, Unions, and Government Intervention. Journal of Public Economics, 55, 185-201.

Schmidt, Christoph M. and Klaus F. Zimmermann (1992), Migration Pressure in Germany: Past and Future. In: Zimmermann, Klaus F. (ED.): Migration and Economic Development. Berlin: Springer, 207-236.

Statistisches Bundeamt (2001), Statistisches Jahrbuch für die Bundesrepublik Deutschland 2001, Wiesbaden.

Vogler, Michael and Ralph Rotte (2001), The Effects of Development on Migration: Theoretical Issues and New Empirical Evidence. Journal of Population Economics, 13, 485-508.

Yuengert, A. M. (1994), Immigrant Earnings Relative to What? The Importance of Earnings Function Specification and Comparison Points. Journal of Applied Econometrics, 9, 71-90.

Zimmermann, Klaus F., Thomas K. Bauer, Holger Bonin, Rene FAhr and Holger Hinte (2002), Arbeitskräftebedarf bei hoher Arbeistlosigkeit - Ein ökonomisches Zuwanderungskonzept für Deutschland (Demand for Workers in Times of High Unemployment). Berlin/Heidelberg: Springer-Verlag. 


\section{Appendix}

Table A1: Description of Explanatory Variables

\begin{tabular}{l|l}
\hline \hline VARIABLE & DESCRIPTION \\
\hline German Nationality* & $\begin{array}{l}\text { Takes the value of } 1 \text { if the respondent is a citizen of Germany; } \\
0 \text { otherwise } \\
\text { Takes the value of } 1 \text { if the respondent is a citizen of France; } \\
0 \text { otherwise } \\
\text { Takes the value of } 1 \text { if the respondent reported foreign } \\
\text { language skills; } 0 \text { otherwise } \\
\text { Visited Foreign Country }\end{array}$ \\
$\begin{array}{l}\text { Takes the value of } 1 \text { if the respondent reported that he/she } \\
\text { has visited a foreign country within the last two years } \\
\text { before the interview; } 0 \text { otherwise } \\
\text { Takes the value of } 1 \text { if the respondent is female; }\end{array}$ \\
Still Studying & $\begin{array}{l}0 \text { otherwise } \\
\text { Takes the value of } 1 \text { if the respondent reported that he/she is } \\
\text { still studying; } 0 \text { otherwise } \\
\text { Takes the value of } 1 \text { if the respondent reported that he/she } \\
\text { feels uneasy in the presence of people of another } \\
\text { nationality, race, religion, or culture; } 0 \text { otherwise } \\
\text { Takes the value of } 1 \text { if the respondent reported that his/her } \\
\text { parents are unemployed; } 0 \text { otherwise } \\
\text { Takes the value of } 1 \text { if the respondent reported that his/her } \\
\text { parents have a high schooling degree; } 0 \text { otherwise }\end{array}$ \\
Parents are Unemployed \\
Parents have a \\
High Degree of Education
\end{tabular}


Table A2: Descriptive Statistics

\begin{tabular}{l|cc}
\hline \hline VARIABLE & MEAN & STANDARDERROR \\
\hline Dependent Variables: & & \\
Ability to go wherever I want & 0.4186 & 0.4934 \\
Not interested in studying/working abroad & 0.0724 & 0.2591 \\
Administrative Diffculties & 0.0660 & 0.2484 \\
Right to work in any EU country & 0.6312 & 0.4826 \\
Explanatory Variables: & & \\
German Nationality & 0.4430 & 0.4968 \\
French Nationality & 0.2694 & 0.4437 \\
Speaks Foreign Language & 0.7239 & 0.4471 \\
Visited Foreign Country & 0.6549 & 0.4755 \\
Being Female & 0.4980 & 0.5001 \\
Still Studying & 0.5046 & 0.5001 \\
Xenophobic Tendency & 0.0798 & 0.2710 \\
Parents are Unemployed & 0.0427 & 0.2022 \\
Parents have a High Degree of Education & 0.2219 & 0.4156 \\
\hline \hline
\end{tabular}

* All variables are categorical. Number of observations: 2,695. 


\section{IZA Discussion Papers}

No. Author(s)

432

A. D. Kugler

J. D. Angrist

A. D. Kugler

G. S. Epstein

M. E. Ward
A. Kunze

M. Fertig

A. Voicu

G. Fella

P. Manzini

M. Mariotti
G. Bertola
S. Hochguertel
W. Koeniger

C. W. Sibley

P. P. Walsh

\section{Lindahl}

K. L. Papps

J. O. Newell

R. Lalive
J. Zweimüller

E. Yashiv

M. Fertig

C. M. Schmidt
Title

Area

Date

Employment, Wages, and Alcohol Consumption

4

in Russia: Evidence from Panel Data

Protective or Counter-Productive? Labor Market 3 Institutions and the Effect of Immigration on EU Natives

From Severance Pay to Self-Insurance: Effects 4 of Severance Payments Savings Accounts in Colombia

Perceived Income, Promotion and Incentive 1

02/02 Effects

The Evolution of the Early Career Gender Wage $\quad 1$ Gap

Evaluating Immigration Policy Potentials and Limitations

Employment Dynamics in the Romanian Labor Market: A Markov Chain Monte Carlo Approach

4

Does Divorce Law Matter?

Dealer Pricing of Consumer Credit

Earnings Inequality and Transition: A Regional 4

02/02 Analysis of Poland

Estimating the Effect of Income on Health and Mortality Using Lottery Prizes as Exogenous Source of Variation in Income

Identifying Functional Labour Market Areas in

02/02 New Zealand: A Reconnaissance Study Using Travel-to-Work Data

Benefit Entitlement and the Labor Market:

Evidence from a Large-Scale Policy Change

Macroeconomic Policy Lessons of Labor Market $\quad 6$ Frictions

Mobility within Europe - What do we (still not) 03/02 